\title{
Implementation of Geoportal for Cultural Heritage Preservation of Penanggungan and Trowulan
}

\author{
Lalu Muhamad Jaelani ${ }^{1}$ and Jayed Ali Bachtiar ${ }^{1}$ \\ Dept. of Geomatics Engineering, Institut Teknologi Sepuluh Nopember, Surabaya, Indonesia- 60111 \\ *Corresponding Address: Lmjaelani@geodesy.its.ac.id
}

\begin{abstract}
Cultural heritage is a cultural richness of the nation as a manifestation of human life's, thoughts and behaviors that are important for understanding the history as well as the science and culture of our ancestors. In East Java there are two cultural heritage areas have been selected by the government: Penanggungan (as of January 14, 2015) and Trowulan (as of December 30, 2013) as provincial and national cultural heritages, respectively. In this research, we built a geoportal data infrastructure for collecting, storing and visualizing the spatial distribution of cultural heritages in these two areas as one of the role in maintaining the preservation of cultural heritages. Based on our geoportal data, the location of cultural heritage located in the elevation ranged from $228 \mathrm{~m}-1330 \mathrm{~m}$ (above sea level). The lowest cultural heritage was Situs Belahan and the highest one was Temple of Kama I. Trowulan Site has 75 artifact findings. This indicated that the Trowulan Site area was a residential area. While in Penanggungan site, the heritage was dominated by cultural object in the form of temple (about 32 object). It might be an indicator that Penanggungan site was a basis for ancient community worship rituals.
\end{abstract}

Keywords—Heritage preservation, Geodatabase, Geoserver, Openlayer

\section{INTRODUCTION}

$\mathrm{C}$

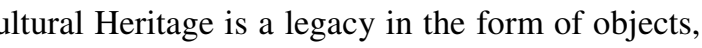

buildings, structures, sites, and location on land and / or water that need to be preserved because it has important values for history, science, education, religion, and / or culture through the process of governmental decree [1]. There are 4 (four) important things inherent and become the point of emphasis on cultural heritage as contained in its definition, i.e.: 1) the material heritage, 2) need to be preserved, 3) have important value, and 4) the process of decree.

The cultural heritage owned by Indonesian needs to be preserved by registering all of legacy to government. Therefore, one of the related effort is by developing a geographic information system in the form of cultural heritage geoportal containing all related-cultural heritage data and stored centrally.

Geoportal is a system that can be connected to the Internet network that used to collect, store, analyze and display a georeferenced information data or data that identifies the location of the object without the need for the use of Geographic Information System (GIS) software at the client side [2]. The objectives of this research included the availability of spatial-based information systems in the form of geoportal that displays the data of cultural heritage site of Trowulan and Penanggungan. All data can be updated regularly and accessed openly. This tool can facilitate the government to collect, stored, manage, and utilize cultural heritage objects in cultural heritage, especially in Trowulan and Penanggungan, East Java.

\section{METHOD}

\section{A. Study Area}

This research was performed on Trowulan Site and Gunung Penanggungan Site, both located in Mojokerto Regency, East Java Province. This regency is included in the strategic area of East Java, namely "Gerbangkertasusila" area located at $7^{\circ} 17^{\prime}-7^{\circ} 45^{\prime}$ SL and $111^{\circ} 19^{\prime}-112^{\circ} 39^{\prime} \mathrm{EL}$

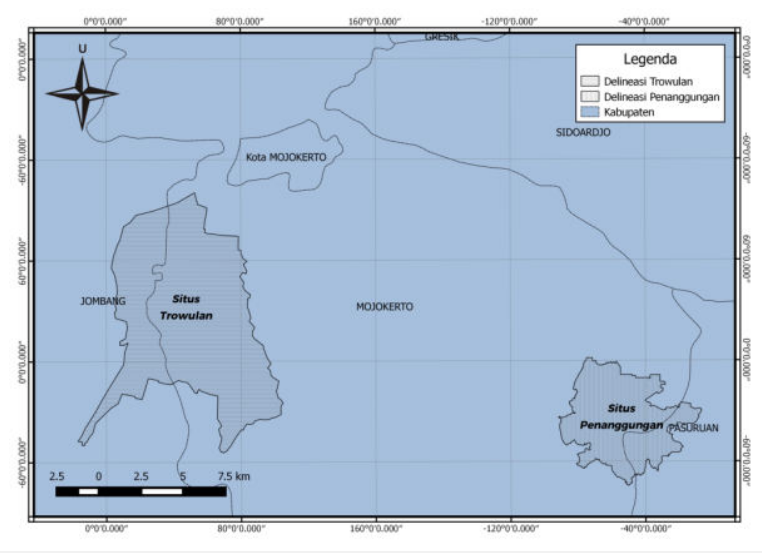

Figure 1. Study area of this research

\section{B. Data and Software}

The data used in this study was spatial data in the form of shapefile for building, structure, site and heritage area collected from cultural conservation authority (Balai Pelestarian Cagar Budaya) and administrative boundaries area collected from Geospatial Information Agency (BIG). 
The supporting data in this research were descriptive attribute data and corresponding photos of each cultural heritage objects. These data were collected by direct field survey and online data collection.

Several opensource softwares such as QGIS as a shapefile data processor, PostGIS as a database management, uDig as a data converter from shapefile to XML format, and Geoserver as a provider of online spatial data management services were used.

\section{Research Model}

\section{(1) Data Collection}

There were two types of data used in this study: primary data, in form of spatial data collected directly using handheld GPS on the field as well as its corresponding information (e.g. photo); and secondary data, in form of all data collected from other institution such as cultural conservation authority and geospatial information agency. This second type of data included literature data and related online data.
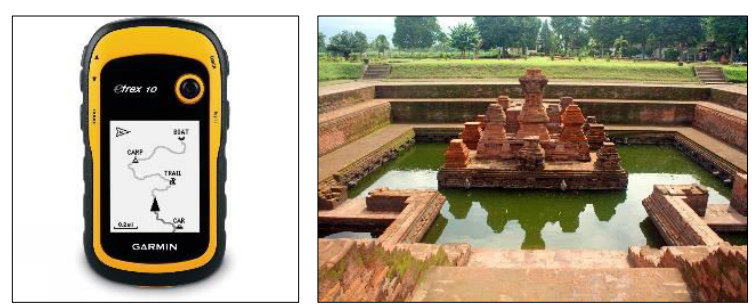

Figure 2. (a) GPS GPS tool for collecting data and (b) cultural heritage Tikus Temple in Trowulan

\section{(2) Data Processing}

Several data stored in analog format (e.g. paper) were converted into digital data in the form of shapefile using QGIS software. QGIS is an open source and free GIS software for geospatial data processing purposes [4].

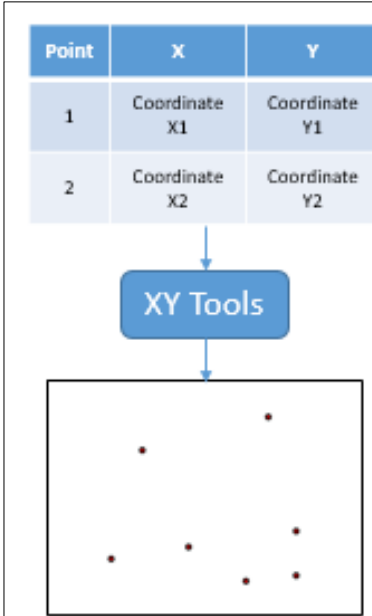

(a)

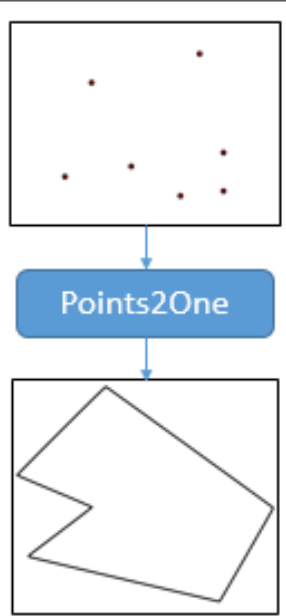

(b)
Figure 3. Step by step (a) convert excel to point (b) convert point to polygon
After all data in shapefile format, these data were stored in a geodatabase as a geoportal content. Development of geodatabase was performed using PostgreSQL with extension of PostGIS. Geo/spatial database has an advantage in storing, managing and analyzing of spatial objects as well as in general database [5].

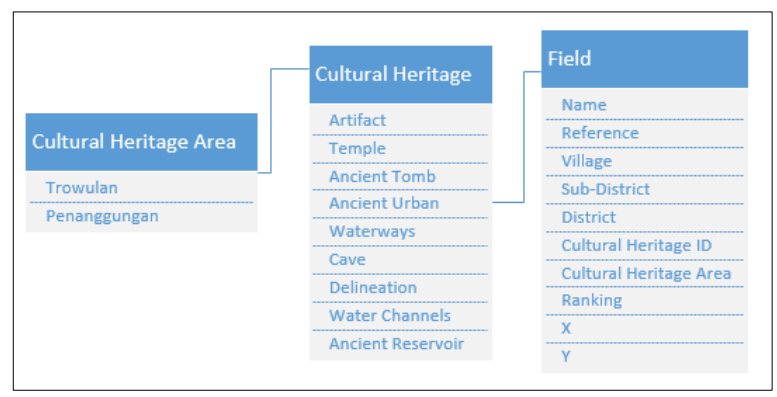

Figure 4. Cultural heritage database scheme

All spatial objects (shapefile) were stored in geodatabase in standard display format. Therefore, $\mathrm{uDig}$ software was used to improve the display following the user need. The output of uDig processing was the XML code of each shapefile. XML is a markup language designed specifically for the delivery of information through the World Wide Web (WWW). XML is a textbased data format that helps developer and provider in describing, sending and exchanging structured data from among various applications to users for the purposes of manipulation [6]

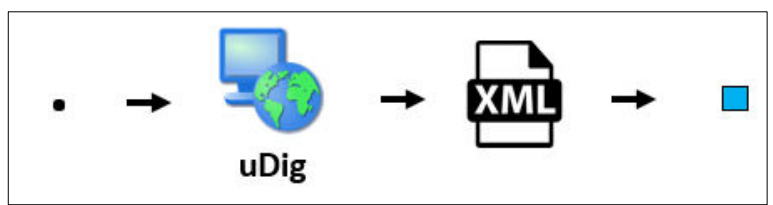

Figure 5. The process of turning a point into a styled point

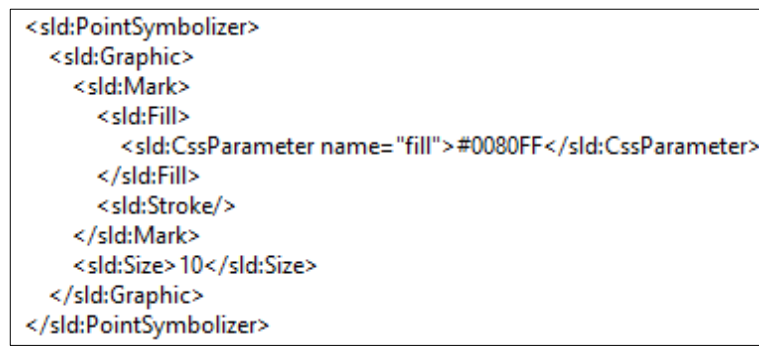

Figure 6. The contents of the SLD file that change the point

The uDig XML output code was inputted into the geoserver software. GeoServer is a java based open source server software that allows users to view and modify geospatial data. GeoServer is cross-operating system (interoperable), can publish spatial data using open standards [5].

OpenLayers was used to read geospatial data that store in geoserver. Openlayers is a javascript-based client application for displaying map data on a web browser 
and is not dependent on the web server being used. Openlayers implements the JavaScript API used to build web-based GIS applications. Openlayers is similar to Google Maps and MSN's Virtual Earth API, with one important difference: OpenLayers is free software, developed for and by the Open Source software community[7]

Integration between PostGIS Databases, Geoserver spatial servers, and Openlayer were built in Palapa applications (developed by Geospatial Information Agency of Infonesia). Palapa is an open source networkbased node application that support the organization of geospatial information management including collection, storing and dissemination.

Here is a chart of how the palapa application works :

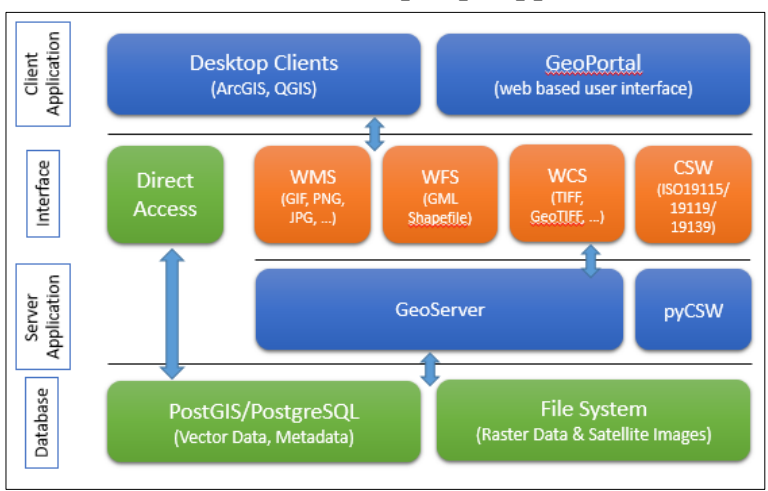

Figure 7. Palapa Application workflow

The Palapa application was installed on a computer server that was connected to public internet network. Palapa was installed on Centos 7 OS and set up with Public IP which was mapped on the domain of http://peta.its.ac.id/.

\section{(3) Data Visualization}

The final result of this research was a Geoportal of Cultural Heritage for Trowulan and Penanggungan and share openly as a web service. The Web is one of the most popular TCP / IP services in providing convenience information [8]. Web works with the concept of client side, which is a system that requests data or services to the webserver. Then, the webserver will provide the data or services requested by the web client. Communication between webserver and web client by sending and receiving web documents through a protocol called Hypertext Transfer Protocol (HTTP). HTTP serves to define and explain how webserver and web client interact in sending and receiving web documents.

\section{RESULTS AND DISCUSSION}

Relationship between object and its field was design in ER diagram. The sample of database ER diagram of Trowulan and Penanggungan site was presented in Figure 8. The result of this research was a database system that collects all data both spatial and non spatial data that was connected with the data manager such as Geoserver and OpenLayer as the data visualization side.

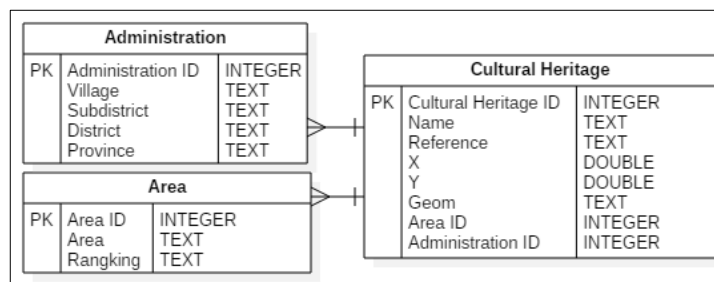

Figure 8. Sample of Geodatabase ER Diagram for Cultural Heritage

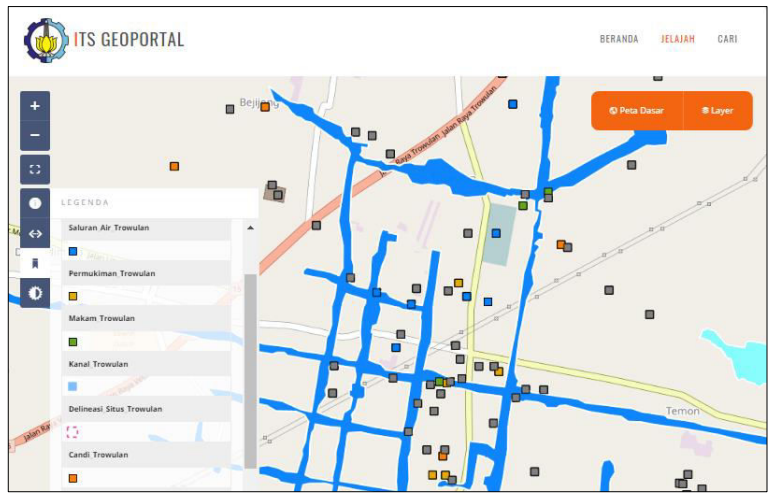

Figure 9. Cultural Heritage Map of Trowulan

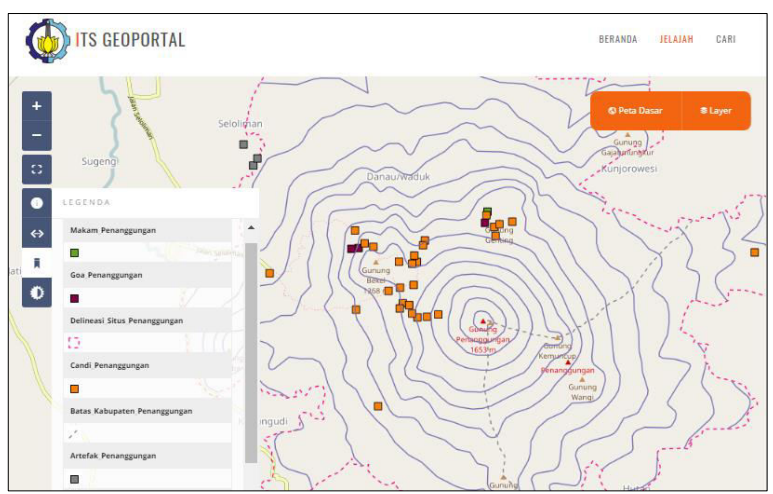

Figure 10. Cultural Heritage Map of Penanggungan

At client side, the output of geosperver was an online geographic information system (web-GIS) that was opened by using openlayer framework. This framework can be opened from developed geoportal. The visualization of Trowulan and Penanggungan in openlayer framework was presented in Figure 9 and 10, respectively.

Palapa Geoportal has a variety of features that support the digital mapping process. All processes can be performed online via geoportal web pages. Palapa application has been grouped the user into 3 levels : (general) user who can search and visualize the geospatial data and information available on the node; Administrator who has has no permission to upload, manage and share data, and Developer who has permission to customize the system. 
This geoportal equipped by two base map alternative: a base map of RBI (Indonesia's topographic map) and Openstreet Map. Figure 11 showed the menu for base map selection.

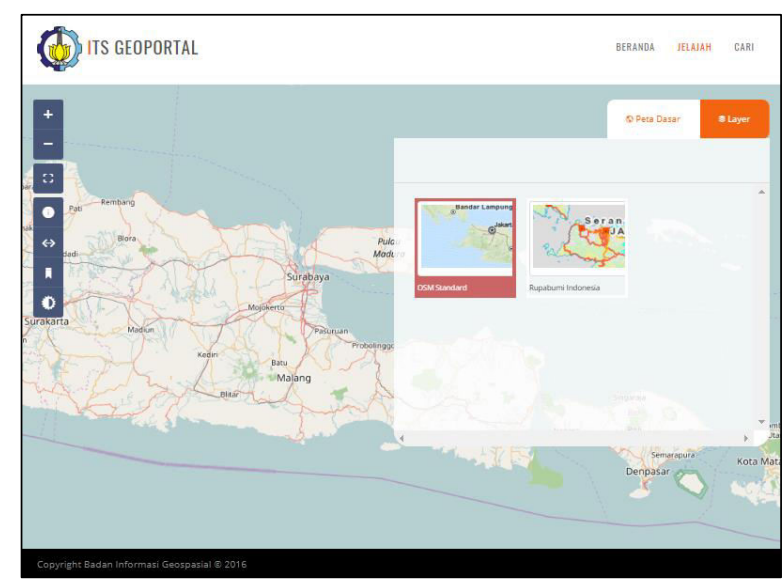

Figure 11. Web page for basemap selction

All geospatial data were stored as layers in database. Users can manage the layer (adding or deleting) according to data they want to view/ analyze. The tool for selecting layers was presented in Figure 12:

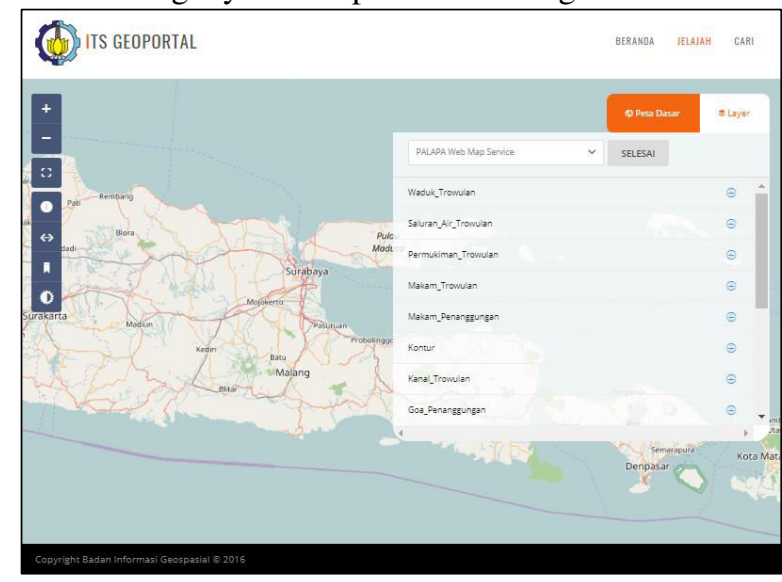

Figure 12. Web page for layer management

Cultural heritage objects showed in Table 1 consists of 101 objects in Trowulan and 39 objects in Penanggungan sites. In Trowulan Site there were 5 types of cultural heritage objects: Temple, Ancient Tombs, Ancient Settlements, Water Channels, and Artifacts.

While in Penanggungan, there were 4 types: Temple, Cave, Ancient Tomb and Artifact. The location of cultural heritage lies in the elevation rangef from $228 \mathrm{~m}$ $1330 \mathrm{~m}$ (above sea level). The lowest cultural heritage was Situs Belahan and the highest one was Temple of Kama I.

Trowulan Site has 75 artifact findings. This indicated that the Trowulan Site area was a residential area. While in Penanggungan site, the heritage was dominated by cultural object in the form of temple (about 32 object). It

Table 1. List of Heritage Objects

\begin{tabular}{clcc}
\hline No & \multicolumn{1}{c}{ Type } & Trowulan & Penanggungan \\
\hline $\mathbf{1}$ & Temple & 8 & 32 \\
$\mathbf{2}$ & Cave & 0 & 3 \\
$\mathbf{3}$ & Ancient Tomb & 5 & 1 \\
$\mathbf{4}$ & Ancient Urban & 5 & 0 \\
$\mathbf{5}$ & Waterways & 8 & 0 \\
$\mathbf{6}$ & Artifact & 75 & 3 \\
\hline & Total & 101 & 39 \\
\hline
\end{tabular}

might be an indicator that Penanggungan site was a basis for ancient community worship rituals.

\section{CONCLUSION}

One of the efforts to preserve the cultural heritage especially in Trowulan and Penanggungan is by registering all heritage objects into the Geoportal system. Development of cultural heritage geoportal through data collection process, data storing using PostgreSQL, data processing using QGIS and Geoserver, improving view of maps using uDig, and data visualization using Openlayers. All these functions are owned by the Palapa application developed by Geospatial Information Agency of Indonesia.

\section{REFERENCES}

[1] Kementerian Pendidikan dan Kebudayaan, UndangUndang Republik Indonesia Nomor 11 Tahun 2010 Tentang Cagar Budaya. 2010.

[2] M. Painho, "WebGIS as a Teaching Tool," Proc. ESRI UC, 2001.

[3] Afrizal, A. Sukmaaji, and T. Sutanto, "Android Personel Monitoring Location pada Institusi Kepolisian Berbasis Web," vol. 3, no. 2, 2013.

[4] P. Oswald and R. Astrini, "Modul Pelatihan Quantum GIS Tingkat Dasar,” 2012.

[5] Kementerian Riset dan Teknologi, "Opengeo Suite dan Ina- Geoportal," vol. 2011, no. 1997, pp. 20072010, 2009.

[6] F. Samopa, D. H. Murti, and O. Oktanio, "Sistem Query pada Dokumen XML dengan Menggunakan Bahasa SQL," JUTI J. Ilm. Teknol. Inf., vol. 4, no. 2, p. 133, Jul. 2005.

[7] Budiawan, "Aplikasi GIS Berbasis WEB Menggunakan Geoserver pada Sistem Informasi Trafo Gardu Induk di PLN Surabaya," Undergrad. Thesis, Informatics Eng. RSIf 025.069 1 Bud a, 2010, 2010.

[8] A. A. Hartanto and O. W. Purbo, Buku Pintar Internet: Teknologi E-Learning Berbasis PHP dan MySQL. Jakarta: Elex Media Komputindo, 2002. 